\title{
EFFECT OF THE DISTANCE BETWEEN THE CUTTING DISC AND FURROW OPENERS EMPLOYED IN ROW CROP PLANTING ON SOIL MOBILIZATION
}

\author{
Tiago R. Francetto ${ }^{1 *}$, Airton dos S. Alonço ${ }^{1}$, Rafael S. Becker ${ }^{1}$, \\ Vitor P. Scherer ${ }^{1}$, Mateus P. Bellé
}

\author{
${ }^{1 *}$ Corresponding author. Universidade Federal de Santa Maria (UFSM), Laboratório de Pesquisa e Desenvolvimento de \\ Máquinas Agrícolas (LASERG)/ Santa Maria - RS, Brasil. \\ E-mail: tiago.francetto@ufsm.br| ORCID ID: https://orcid.org/0000-0001-7287-5920.
}

\section{KEYWORDS}

agricultural engineering, machinery-soil relation, agricultural machinery, field test, direct planting.

\begin{abstract}
The objective of this study was to determine the effect of the longitudinal distance between a cutting disc and a fertilizer furrow opener on the operational performance of the furrow opener working at different forward speeds during soil mobilization. The soil in the experimental area was classified as Typic Hapludalf with a loam soil texture. The experiment involved 24 treatment combinations in a $2 \times 3 \times 4$ factorial scheme. These combinations were formed by the interaction of the following factors: furrow opening mechanisms, longitudinal distance from the center of the cutting mechanism to center of the furrow opener, and forward speeds. The effects of the tools on the soil mobilization variables were characterized in three phases: analysis of the natural profile and elevation and mobilization of the soil using a microprofilometer. A statistical analysis of variance was performed on the acquired data and the significance of the factors was verified using an $\mathrm{F}$ test. The furrow opener factor significantly substantially influenced all variables, whereas the distance significantly modified only the soil swelling and elevated soil area, with a reduction of approximately $30 \%$ in this variable when separating the mechanisms by an additional meter. Likewise, for a hoe furrow opener, the speed significantly influenced only the maximum depth of the furrow. Hence, we recommend the installation of fertilizer furrow openers close to the cutting mechanisms to increase the quality of the furrows produced in seeding operations using the direct planting system.
\end{abstract}

\section{INTRODUCTION}

Agricultural mechanization describes the application of technology in agricultural development. In many countries, investigations regarding this subject have enabled an increase in the productivity of cultures and significant advances in the search for increased efficiency of agricultural operations. Applying such mechanized innovations actively seeks specific solutions to social, economic, and technical problems (Daum \& Birner, 2020; Loon et al., 2020; Amoozad-Khalili et al., 2020; Paudel et al., 2019; Aguilera et al., 2019).

One specific innovation, which fostered the evolution of Brazilian agriculture, was the development of a direct planting system (DPS). Its implementation advocates the adoption of minimal soil revolving (Büchi et al., 2019), the maintenance of a considerable amount of vegetable residue on the surface (Nunes et al., 2018), and the practice of a culture rotation program (Skaalsveen et al., 2020). By enabling countless advantages to the production process, the growth of the area seeded with this system in different countries experienced exponential implementation beginning in the 1980s according to Nunes et al. (2018).

However, owing to the reduction in the amount of mechanical intervention during the implementation of the DPS as described, inadequate application may cause high interference in culture productivity (Jabro et al., 2021; Liu et al., 2016; Nawaz, et al., 2016; Dang et al., 2015). Hence, there is a significant need for improved seeders and

${ }^{1}$ Universidade Federal de Santa Maria (UFSM), Laboratório de Pesquisa e Desenvolvimento de Máquinas Agrícolas (LASERG)/ Santa Maria - RS, Brasil.

${ }^{2}$ Instituto Federal de Santa Catarina/ São Carlos - SC, Brasil. 
mechanisms capable of performing their functions with quality and reduced energy demand, from the dosage and distribution of inputs (Carpes et al., 2017) to the opening and closing of the furrow (Francetto et al., 2016).

Consequently, the mechanisms for shearing the residues of cultures and formation of the furrow, in addition to adjusting the distance between furrows, were idealized for conducting such tasks. Mechanisms include the so-called triple disc (cutting disc and double-disc furrow opener), enlarged blade (spaced cutting mechanism and hoe furrow opener), and the guillotine blade (close cutting disc and hoe furrow opener).

However, the arrangement of these mechanisms may present differences in performance under similar work conditions, altering the intensity and direction of some performance variables due to changes in the distance between mechanisms. Performance differences could also be amplified by operational adjustments, such as forward speed (Francetto et al., 2016; Hasimu \& Chen, 2014; Solhjou et al., 2014). This work demonstrated that it is possible to identify and measure the operational behavior of furrow openers following such adjustments, obtaining beneficial and reliable results for users and manufacturers. This work may influence future modifications of the current mechanisms to remedy identified difficulties before their application in specific machines.

Thus, the objective of this work was to determine the effect of the longitudinal distance between the culture residue cutting disc and the fertilizer furrow opener on the operational performance of the furrow opener, while working at varying forward speeds. Furrow quality was analyzed through soil mobilization variables.

\section{MATERIAL AND METHODS}

\section{Localization and characterization of the experimental area}

The experiment was performed in an agricultural area situated in the municipality of Santa Maria (Rio Grande do Sul, Brazil) and belonging to the Federal
University of Santa Maria (UFSM). The geographical coordinates of the location are 29 43'29.16" $\mathrm{S}$ and $53^{\circ} 43^{\prime} 40.61^{\prime \prime} \mathrm{W}$ (central point), with an average altitude of $106 \mathrm{~m}$ above sea level.

We quantified the presence of crop residue dry matter over the soil surface in a $1 \mathrm{~m}^{2}$ sample per experimental parcel, through the electrical hothouse drying method with forced air ventilation regulated at a temperature of $70^{\circ} \mathrm{C}$. The mean value obtained was $55.78 \mathrm{~g} \mathrm{~m}^{-2}$.

Physical characterization of the soil was conducted through the collection of field samples at depths of $0-0.20$ $\mathrm{m}$, with subsequent analyses in the Laboratory of Agricultural Machinery Research and Development (LASERG) following the methodology proposed by EMBRAPA (1997) for determination of soil density and water content.

The determination of the soil consistency regarding the change from the liquid to the plastic state (Atterberg constants for liquidity limit) followed the methodology of the 25 blows. The soil consistency referring to the transition from the plastic to the semi-solid state (Atterberg constants for plasticity limit) was tested according to the methodology proposed by EMBRAPA (1997). The difference between the values indicates the plasticity index of the soil.

The texture characterization of the soil consisted of the adoption of the Vettori method (1969). The soil was classified as Typic Hapludalf (EMBRAPA, 2013) and texturally classified as loam soil.

The resistance of the soil to penetration (RP) was determined using an electronic penetrometer (Falker, model PLG 1020). Data collection was performed at depths from 0 to $0.40 \mathrm{~m}$, with the acquisition of one datum every $0.010 \mathrm{~m}$ of depth. In addition, to obtain the degree of compactness and the optimal water content, we conducted a soil-compacting essay.

Table 1 summarizes the minimal, mean, and maximum values determined for the physical characteristics of the soil.

TABLE 1. Minimum, mean, and maximum values of the physical characteristics of the soil.

\begin{tabular}{|c|c|c|c|}
\hline \multirow{2}{*}{ Characteristics } & \multicolumn{3}{|c|}{ Values } \\
\hline & Minimum & Mean & Maximum \\
\hline Soil density $\left(\mathrm{g} \mathrm{cm}^{-3}\right)$ & 1.10 & 1.55 & 1.89 \\
\hline Water content of the soil $\left(\mathrm{g} \mathrm{g}^{-1}\right)$ & 0.10 & 0.15 & 0.21 \\
\hline Liquidity limit (\%) & - & 33.61 & - \\
\hline Plasticity limit (\%) & - & 30.55 & - \\
\hline Plasticity index (\%) & - & 2.73 & - \\
\hline Percentage of clay $(\%)$ & - & 20.40 & - \\
\hline Percentage of silt (\%) & - & 47.90 & - \\
\hline Percentage of sand (\%) & - & 31.70 & - \\
\hline Resistance to penetration $(\mathrm{kPa})$ & 111.55 & $1,591.48$ & $2,271.61$ \\
\hline Depth of the occurrence of resistance (cm) & 1.00 & - & 11.00 \\
\hline Degree of compaction $\left(\mathrm{g} \mathrm{cm}^{-3}\right)$ & - & 1.69 & - \\
\hline Optimal water content $\left(\mathrm{g} \mathrm{g}^{-1}\right)$ & - & 0.18 & - \\
\hline
\end{tabular}


The usage history of the area is defined by alternation between soybean (Glycine max) and grasses for grazing in the winter period, with ryegrass (Lolium multiflorum) and wheat (Triticum spp.) being the predominant vegetative cover at the time the experiment was conducted.

\section{Description of the factors}

The experiment was composed of the interaction of three different factors, namely, the furrow opening mechanism (Factor 1, with two variables: a hoe furrow opener and a double disc), the longitudinal distance from center to center of the culture residue cutting mechanism and the furrow openers (Factor 2, with three variables: $0.50,1.0$, and $1.50 \mathrm{~m}$ ), and the forward speed (Factor 3, with four variables: $1.11,1.67,2.22$, and $\left.2.78 \mathrm{~m} \mathrm{~s}^{-1}\right)$.

\section{Experimental design and analysis}

In the experimental design random blocks allowed the evaluation of 24 treatments created from the combination of the variables of the three studied factors in a $2 \times 3 \times 4$ factorial $(2$ furrow openers $\times 3$ distances $\times 4$ speeds). We conducted three repetitions for each treatment.

After acquiring the data on the variables, we tested the normality of the errors and homogeneity of the variances using the Kolmogorov-Smirnov and Cochran tests. For this purpose, we used Minitab 17.1.

We submitted the data to statistical analysis of variance and verified the significance of the factors using the $\mathrm{F}$ test. To interpret which treatments differed, we applied the Tukey test at a $5 \%$ and $1 \%$ error probability to compare multiple means in case of double significance between the furrow opener mechanism factor (qualitative) and the distance and/or speed factors (quantitative). We also conducted a regression analysis to express the behavior of such factors mathematically.

\section{Characterization of the mechanized assembly}

The mechanized assembly (A), illustrated in Figure 1 , was characterized by the use of an agricultural tire tractor (B) and a mobile tool-holder structure developed by Gassen (2011) (C) composed of a chassis structure, coupling, wheelsets, and a tool suspension system for maneuvers.
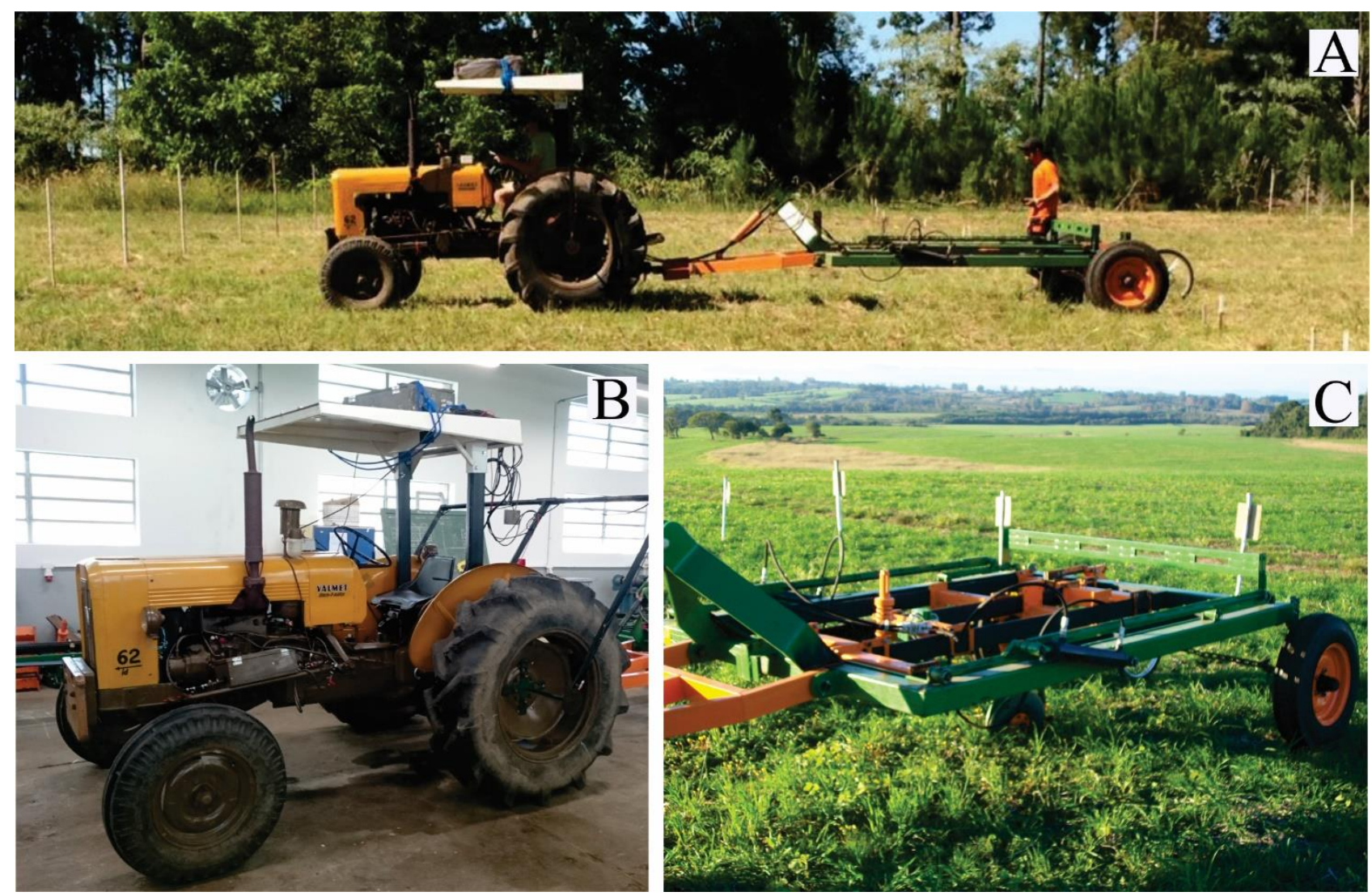

FIGURE 1. Mechanized assembly (a); Agricultural tractor (b); Mobile tool-holder structure (c).

\section{Cutting mechanism for culture residues}

We employed a cutting disc with a smooth coulter (DL), a diameter of $0.46 \mathrm{~m}$, sheet thickness of $0.0044 \mathrm{~m}$, working depth regulated at $0.05 \mathrm{~m}$, and a soil contact surface of $0.1520 \mathrm{~m}^{2}$.

\section{Furrow opening mechanisms}

We used hoe and mismatched double-disc furrow openers with the characteristics summarized in Table 2. 
TABLE 2. Physical characteristics of the furrow openers.

\begin{tabular}{|c|c|c|}
\hline \multirow{2}{*}{ Description } & \multicolumn{2}{|c|}{ Specification } \\
\hline & Hoe & Double-discs \\
\hline Thickness of the rod (m) & 0.01 & - \\
\hline Thickness of the tip (m) & 0.02 & - \\
\hline Angle of attack (rad - degrees) & $0.96-55.00$ & - \\
\hline Diameter $(\mathrm{m})$ & - & 0.39 \\
\hline Mismatched (m) & - & 0.004 \\
\hline Height of the contact point $(\mathrm{m})$ & - & 0.07 \\
\hline Angle between the rotation planes of the discs ( $\mathrm{rad}-$ degrees) & - & $0.21-12.00$ \\
\hline Angle of the horizontal axis with the contact point ( $\mathrm{rad}$ - degrees) & - & $0.70-40.00$ \\
\hline Adjusted work depth (m) & 0.11 & 0.06 \\
\hline
\end{tabular}

\section{Associations between mechanisms for cutting and furrow opening}

Figure 2 presents illustrations and descriptions of the configurations, including longitudinal distance, between the mechanisms that compose association 1 (smooth cutting disc and double-disc furrow opener) and association 2 (smooth cutting disc and hoe furrow opener).
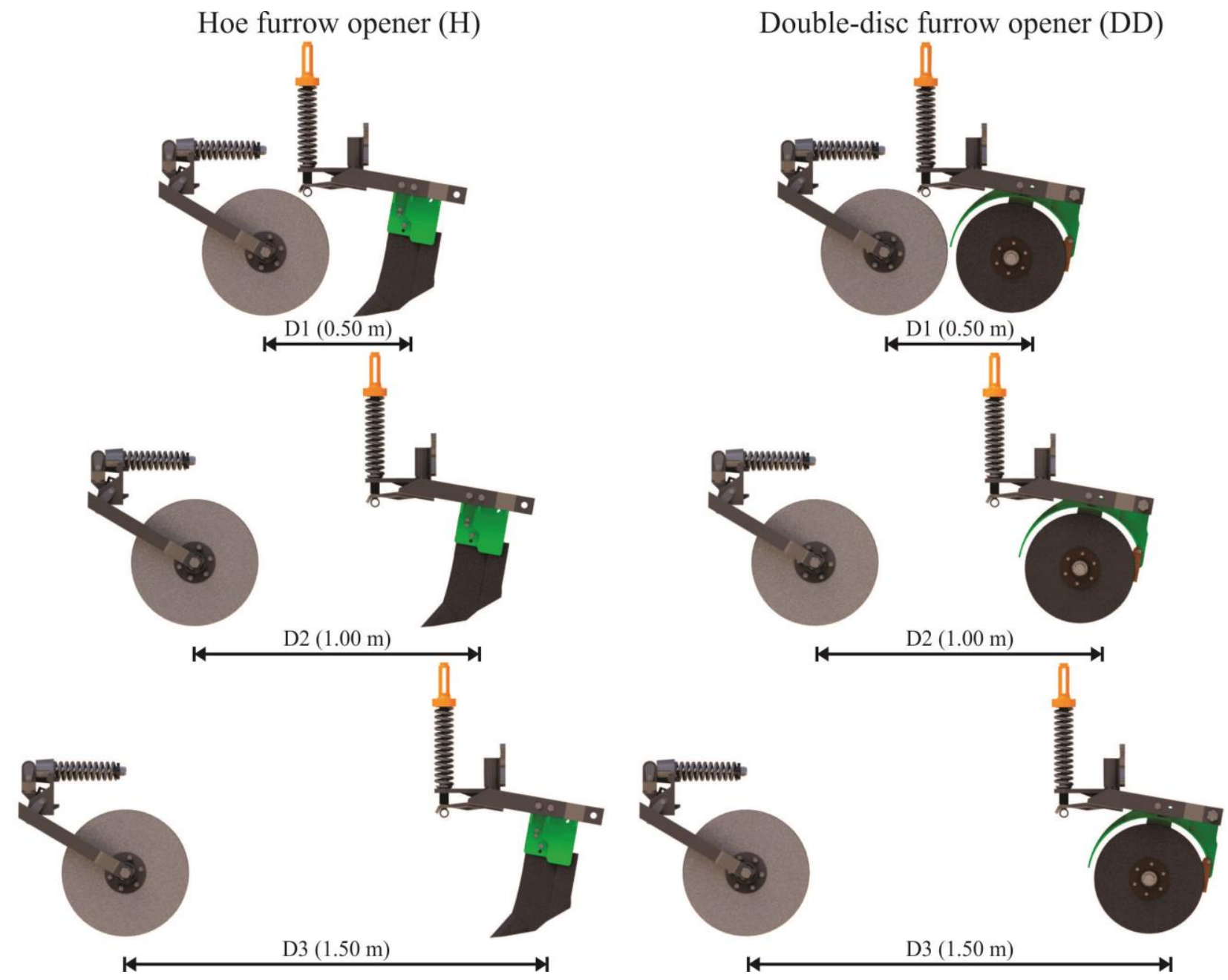

FIGURE 2. Configurations of the elements of tool-holder structure.

\section{Installation and experiment setup}

The experiment was conducted in a total area of $4,320.0 \mathrm{~m}^{2}(72 \times 60 \mathrm{~m})$. This figure does not include the necessary maneuver space. The individual parcels had an area of $180.0 \mathrm{~m}^{2}$ (3.0 m wide by $60.0 \mathrm{~m}$ long). The first dimension was defined by the working width of the tool- holder structure, whereas the second was derived from the ABNT standard 04:015.06-00 (1996).

\section{Data acquisition and soil mobilization}

The characterization of the tool effects on the soil mobilization variables was performed in three steps for each repetition, namely, by obtaining the natural profile 
(phase 1), the profile for elevation (phase 2), and the profile of mobilization (phase 3 ) of the soil. In all steps as illustrated in Figure 3, we used a microprofilometer (A) placed among stakes to signal the analyzed location (B), marking all the profiles of a given repetition on a single A2 sheet of graph paper $(\mathrm{C})$.

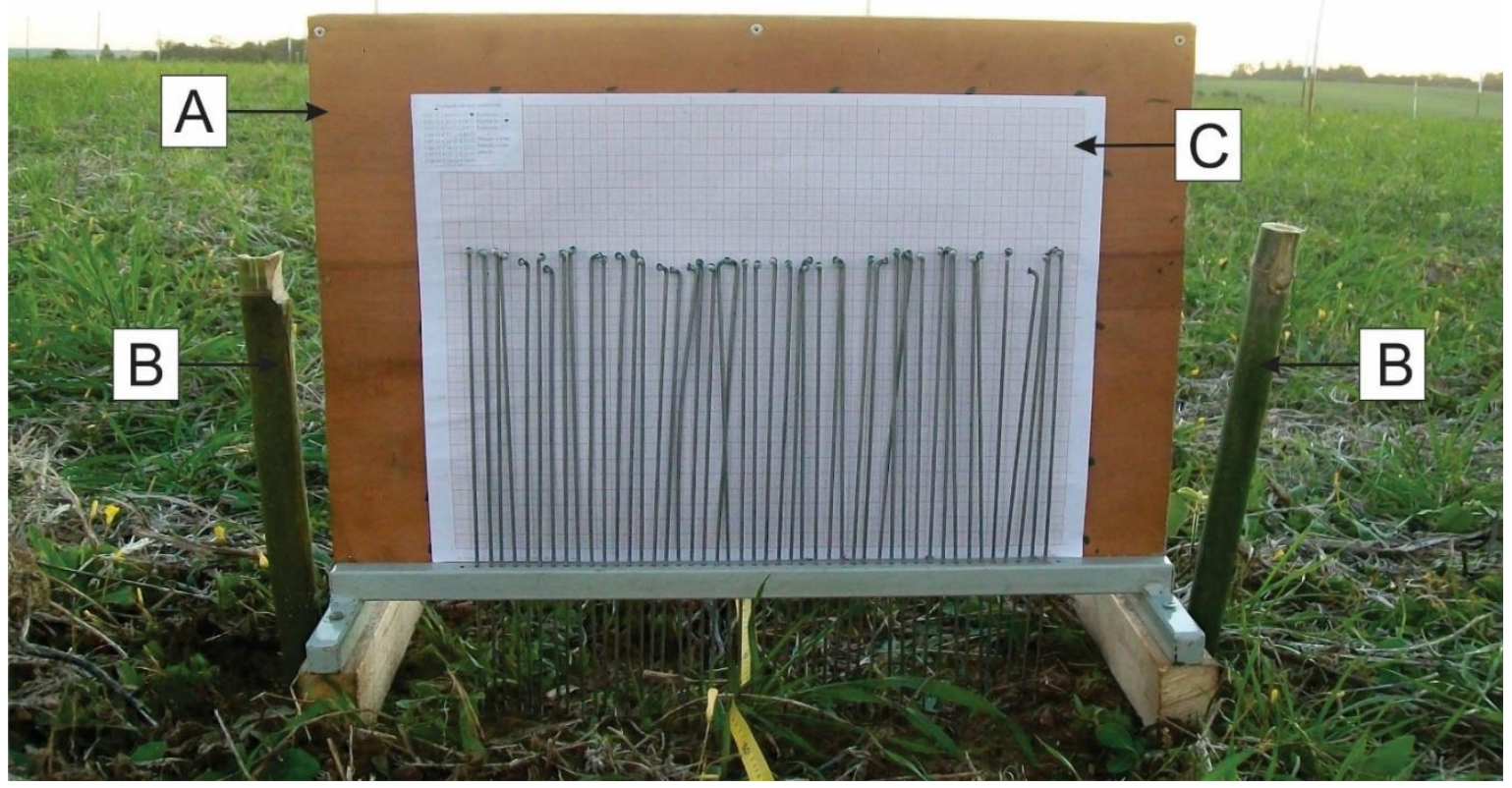

FIGURE 3. Microprofilometer for marking the soil profiles.

Table 3 summarizes the essential tasks for using the microprofilometer for each phase in the order of execution.

TABLE 3. Essential tasks comprising the use of the microprofilometer.

\begin{tabular}{cl}
\hline Phase & Tasks \\
\hline 01 & Demarking the site \\
01 & Positioning of the microprofilometer \\
01 & Marking of the natural profile on graph paper \\
02 & Passing of the tools \\
02 & Positioning of the microprofilometer \\
02 & Marking of the elevated profile on graph paper \\
03 & Manual removal of the soil \\
03 & Positioning of the microprofilometer \\
03 & Marking of the mobilized profile on graph paper \\
\hline
\end{tabular}

After obtaining the profiles marked on paper sheets, they were photographed with a fixed camera ( $\mathrm{x}, \mathrm{y}$, and $\mathrm{z}$ positions). They were then entered into the computational program AutoCAD (1:1 scale) to trace the contour lines of the profiles, and through the use of the software tools for area calculation, we determined the area in square meters.
The space between the first and second profiles defined the elevated soil area (Ae), whereas that between the first and third profiles established the mobilized soil area (Am). In addition, we determined the maximum width $(\mathrm{Lm})$ and depth (Pm) of the furrows, as illustrated in Figure 4.

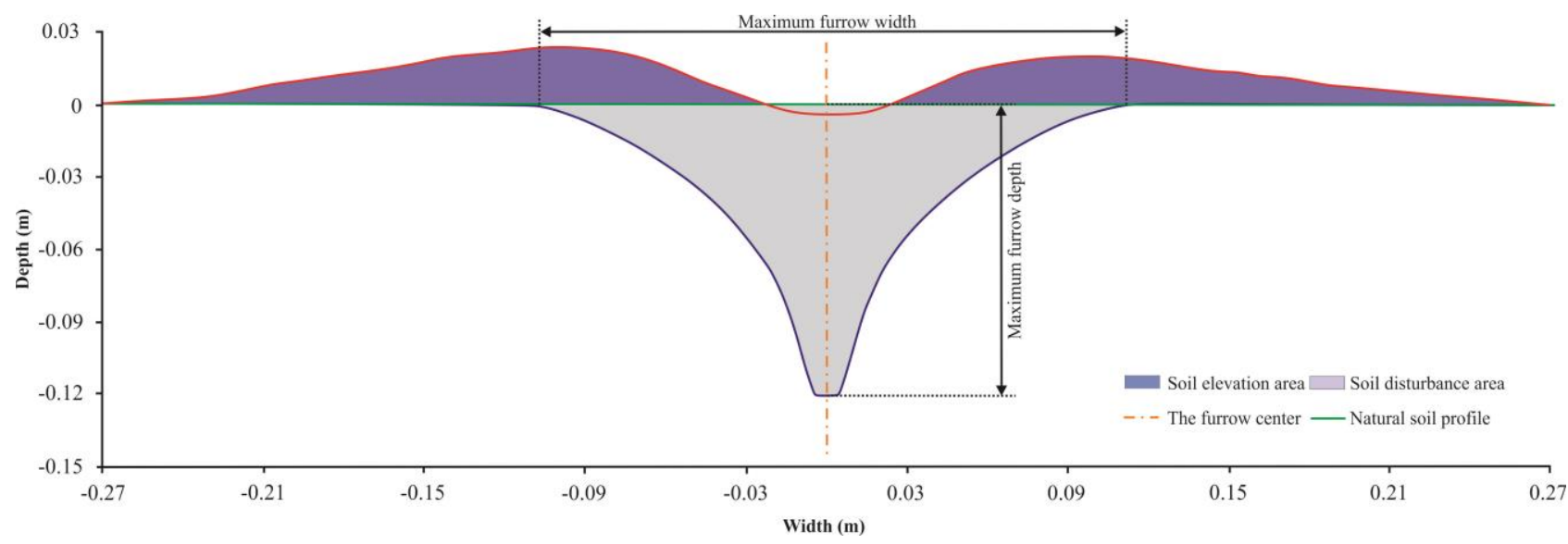

FIGURE 4. Graphical example of the quantitative variables analyzed in the furrow. 
The soil swelling was determined by employing [eq. (1)], obtained from the ratio between the elevated and mobilized soil areas:

$$
E m=(A e / A m) \times 100
$$

Where:

$$
\text { Em = soil swelling }(\%) ;
$$

Ae $=$ elevated soil area $\left(\mathrm{m}^{2}\right)$,

$\mathrm{Am}=$ mobilized soil area $\left(\mathrm{m}^{2}\right)$.

\section{RESULTS AND DISCUSSION}

Table 4 presents the statistical analysis with the mean values, coefficient of variation, and the results of the $\mathrm{F}$ test for the soil mobilization variables.

\begin{tabular}{|c|c|c|c|c|c|}
\hline & \multicolumn{5}{|c|}{ Variables } \\
\hline & $\operatorname{Am}\left(m^{2}\right)$ & $\operatorname{Ae}\left(\mathrm{m}^{2}\right)$ & $\operatorname{Pm}(\mathrm{m})$ & $\operatorname{Lm}(\mathrm{m})$ & $\operatorname{Em}(\%)$ \\
\hline \multicolumn{6}{|l|}{$\mathrm{CV}$ and $\mathrm{OM}$} \\
\hline $\mathrm{CV}(\%)$ & 18.54 & 28.45 & 27.99 & 6.76 & 29.74 \\
\hline Overall mean $(\mathrm{OM})$ & 0.0101 & 0.0030 & 0.0824 & 0.2567 & 27.79 \\
\hline \multicolumn{6}{|l|}{ F Test } \\
\hline Furrow opener (F1) & $22.55^{* *}$ & $32.61 * *$ & $564.54 * *$ & $6.39 *$ & $4.78 *$ \\
\hline Distance (F2) & $0.68 \mathrm{~ns}$ & $3.76^{*}$ & $0.50 \mathrm{~ns}$ & $2.65 \mathrm{~ns}$ & $3.57 *$ \\
\hline Speed (F3) & $1.04 \mathrm{~ns}$ & $0.68 \mathrm{~ns}$ & $3.62 *$ & $2.19 \mathrm{~ns}$ & $0.88 \mathrm{~ns}$ \\
\hline $\mathrm{F} 1 \times \mathrm{F} 2$ & $1.60 \mathrm{~ns}$ & $0.86 \mathrm{~ns}$ & $1.50 \mathrm{~ns}$ & $1.36 \mathrm{~ns}$ & $2.44 \mathrm{~ns}$ \\
\hline $\mathrm{F} 1 \times \mathrm{F} 3$ & $0.34 \mathrm{~ns}$ & $0.36 \mathrm{~ns}$ & $3.39 *$ & $1.12 \mathrm{~ns}$ & $0.29 \mathrm{~ns}$ \\
\hline $\mathrm{F} 2 \times \mathrm{F} 3$ & $0.67 \mathrm{~ns}$ & $0.51 \mathrm{~ns}$ & $0.72 \mathrm{~ns}$ & $0.72 \mathrm{~ns}$ & $0.50 \mathrm{~ns}$ \\
\hline $\mathrm{F} 1 \times \mathrm{F} 2 \times \mathrm{F} 3$ & $0.17 \mathrm{~ns}$ & $0.15 \mathrm{~ns}$ & $0.60 \mathrm{~ns}$ & $0.34 \mathrm{~ns}$ & $0.42 \mathrm{~ns}$ \\
\hline
\end{tabular}

TABLE 4. Statistical analysis for the primary variables of soil mobilization.

**: Significant at $1 \%$ probability $(\mathrm{p}<0.01)$; *: Significant at $5 \%$ probability $(\mathrm{p}<0.05)$; ns: non-significant $(\mathrm{p}>=0.05)$; Am: mobilized soil area; Ae: elevated soil area; Pm: maximum furrow depth; Lm: maximum furrow width.

The furrow opener factor caused significant alterations for all soil mobilization variables, whereas the distance factor significantly modified only the elevated area and soil swelling. Moreover, it was evident that the distance factor is inconsequential to the type of furrow opener and the work speed, given that we did not find a significant interaction between any of these. In turn, the forward speed interacted significantly only with the maximum furrow depth.

The coefficient of variation $(\mathrm{CV})$ presented an overall mean of $22.30 \%$, with wider dispersions for the unit variables of area (mean of $23.49 \%$ ) than for the linear ones (mean of 17.37\%), thus corroborating the results of
Francetto et al. (2016). This may be associated with the variability of the physical attributes in the experimental area, in particular the soil density with a $\mathrm{CV}$ of $7.57 \%$ and $\mathrm{RP}$ of $32.07 \%$. This is a property that is intrinsic to soils, and its importance is accentuated in areas with a direct planting system because management with this system has mixed effects on these properties according to BlancoCanqui \& Ruis (2018).

\section{Area of mobilized soil}

Figure 5 illustrates the variation of the mobilized soil area for both furrow openers. 


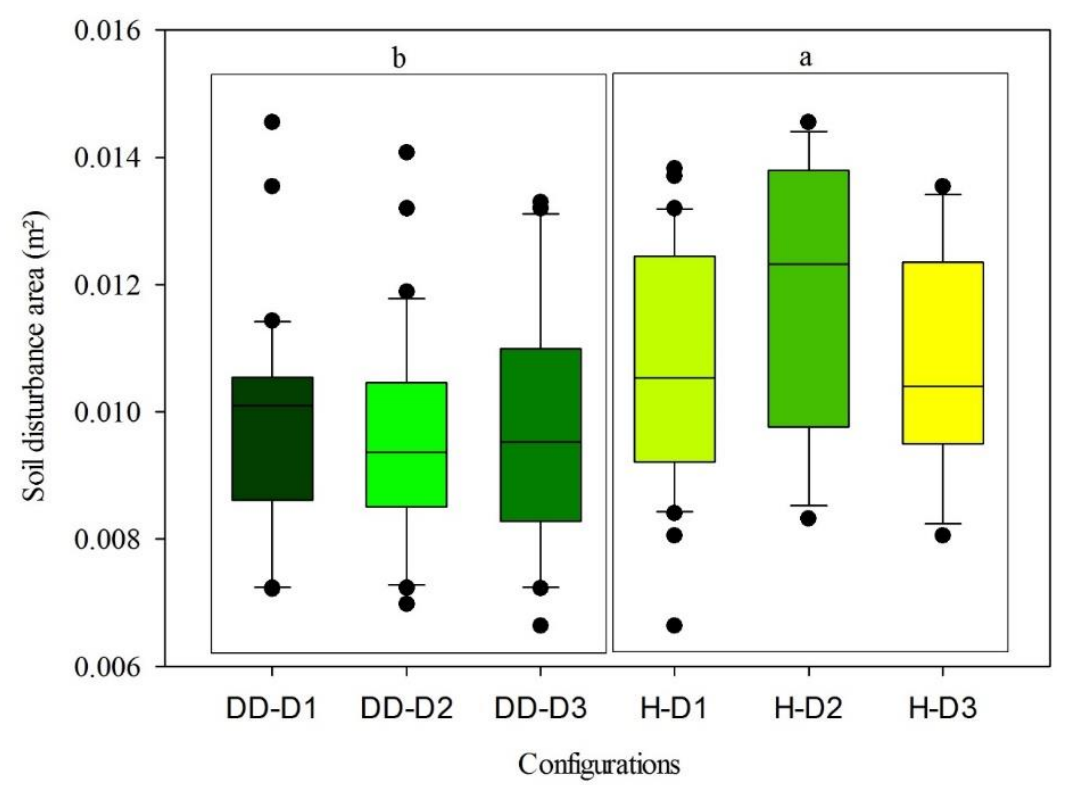

FIGURE 5. Mobilized soil area as a function of the mechanism configurations.

A group of configurations followed by different letters were significantly different according to the Tukey test $(\mathrm{p}<0.05)$.

We verified a statistically significant difference between the mobilized soil area values of the different furrow openers, with $0.0092 \mathrm{~m}^{2}$ for the double disc and $0.0111 \mathrm{~m}^{2}$ for the hoe furrow opener. These values are similar to those found by Francetto et al. (2016), who analyzed soil mobilization by different cutting discs. The difference stems from the distinct working depth (Zeng et al., 2017), which is smaller for the double disc, owing to the different actions in the furrow opening process. These actions confer distinct shearing and compression strengths exerted on the soil by the tools (Sun et al., 2018) due to the physical characteristics of the mechanisms.

For both of the furrow openers, the modification of the distance from the opener to the cutting mechanism did not provide significant changes to the mobilized area, which indicates that this factor is not limiting to the desired furrow mobilization during the seeding process. However, the employment of closer settings $(0.5 \mathrm{~m})$ presented the lowest amplitude of the variable, leading to a more uniform furrow formation along the line. For the double disc, this setting provided up to $30 \%$ more stability in this process; however, for the hoe furrow opener, this value was approximately $65 \%$.

The distance variable may also have suffered interference from the variability of the physical characteristics of the soil local to each treatment, which further supports employing the fertilizer furrow openers close to the cutting discs, given that such changes are inherent to soil and may further improve the quality of the process.

Figure 6 illustrates the soil mobilization as a function of the distinct work speeds employed.

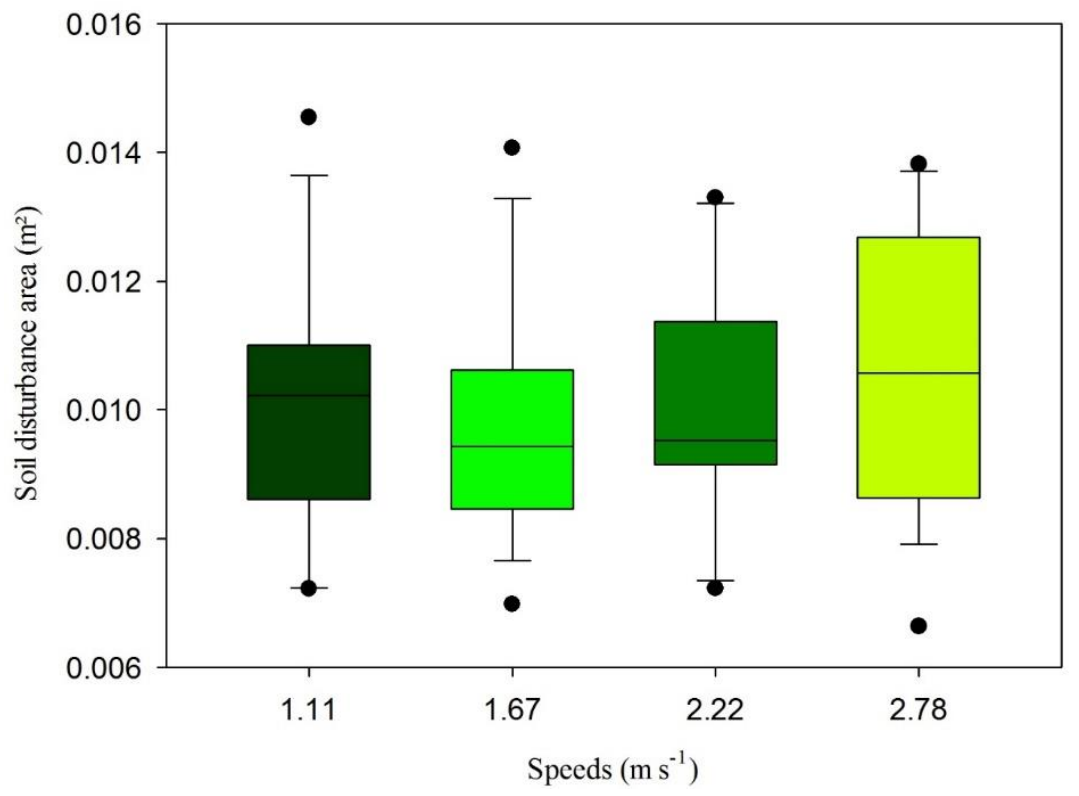

FIGURE 6. Mobilized soil area as a function of the forward speed. 
The employment of different forward speeds of the assembly did not significantly influence the mobilized soil area, which presented an average of $0.0101 \mathrm{~m}^{2}$. This indicates that this factor, similar to the distance, is not limiting for proper mobilization in the furrow for the direct planting system and suggests the possibility of using speeds of up to $2.78 \mathrm{~m} \mathrm{~s}^{-1}$ without causing changes in soil mobilization. These results are in accordance with those found by Silva et al. (2012) when assessing the performance of straw cutting mechanisms, Bellé et al. (2014) and Gassen et al. (2014) when working with scarifiers in a direct planting system, and Francetto et al.
(2016) when analyzing the performance of furrow openers and cutting discs. This effect may have been influenced by the friable consistency of the soil at the time of the experiment, corroborating the results obtained by Casão Junior et al. (2000), who did not find an increase in the mobilized soil area in this moisture condition only.

\section{Area of elevated soil}

Figure 7 illustrates the modification caused by the different furrow openers in soil elevation and the results of the Tukey test.

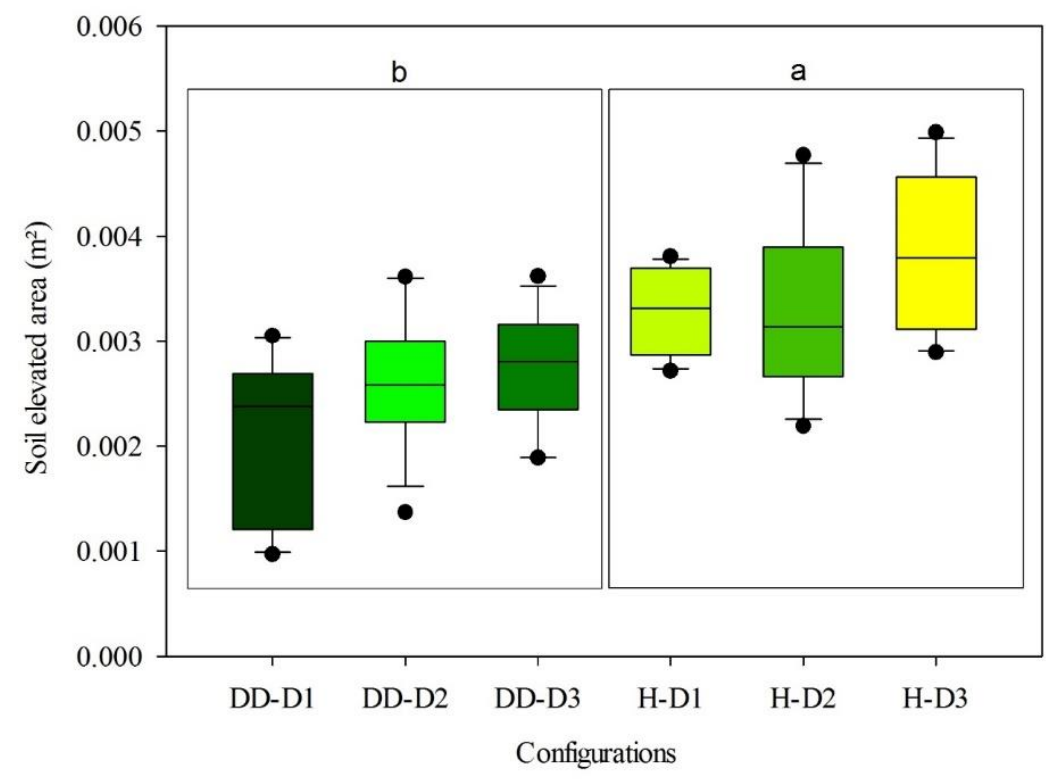

FIGURE 7. Soil elevation as a function of the configurations of mechanisms.

A group of configurations followed by different letters were significantly different according to the Tukey test $(p<0.05)$.

The change in the furrow opener type and its distance from the cutting mechanism provided significant alterations in the elevated soil area variable. However, there was no significant interaction between the factors regarding soil elevation, and the effects of one factor regarding soil elevation did not depend on the level of the other. Hence, as independent factors concerning this variable, the choice of proper setting becomes simpler.

The hoe furrow openers exhibited a mean value of $0.0035 \mathrm{~m}^{2}$, whereas for the disc furrow openers, the mean soil elevation was $0.0025 \mathrm{~m}^{2}$. According to Francetto et al. (2016), this is primarily because the rotating furrow opener is arranged at a smaller depth and promotes narrower furrows, resulting in a smaller elevated soil area; further, the cutting and not shearing action is employed for opening the furrow.

When modifying the distance from the cutting mechanism to the disc furrow opener, we obtained values of $0.0027 \mathrm{~m}^{2}$ at $0.50 \mathrm{~m}, 0.0030 \mathrm{~m}^{2}$ at $1.00 \mathrm{~m}$, and 0.0033 $\mathrm{m}^{2}$ for $1.5 \mathrm{~m}$. Hence, the reduction of this factor enabled a significant drop in soil elevation, with the verification of an area approximately $20 \%$ smaller when the furrow openers were brought closer by one meter. Regression $\mathrm{y}=$ $0.0013 x^{2}-0.0059 x+0.0883\left(R^{2}=1\right)$ describes this result.

Furthermore, the use of more distant settings for both furrow openers presented the most substantial increment in elevated soil area $\left(0.0008 \mathrm{~m}^{2}\right)$ when employing a speed of $2.78 \mathrm{~m} \mathrm{~s}^{-1}$, a value $60 \%$ larger than that found for the other distance settings. Therefore, although this factor did not significantly impact soil elevation, speed selection may affect the final quality of the furrow as a function of the soil projection away from this region (Figure 8). According to Solhjou et al. (2014), this is a limiting factor that rules the current seeding speeds, with the spacing of the mechanisms possibly reducing this adverse effect. 


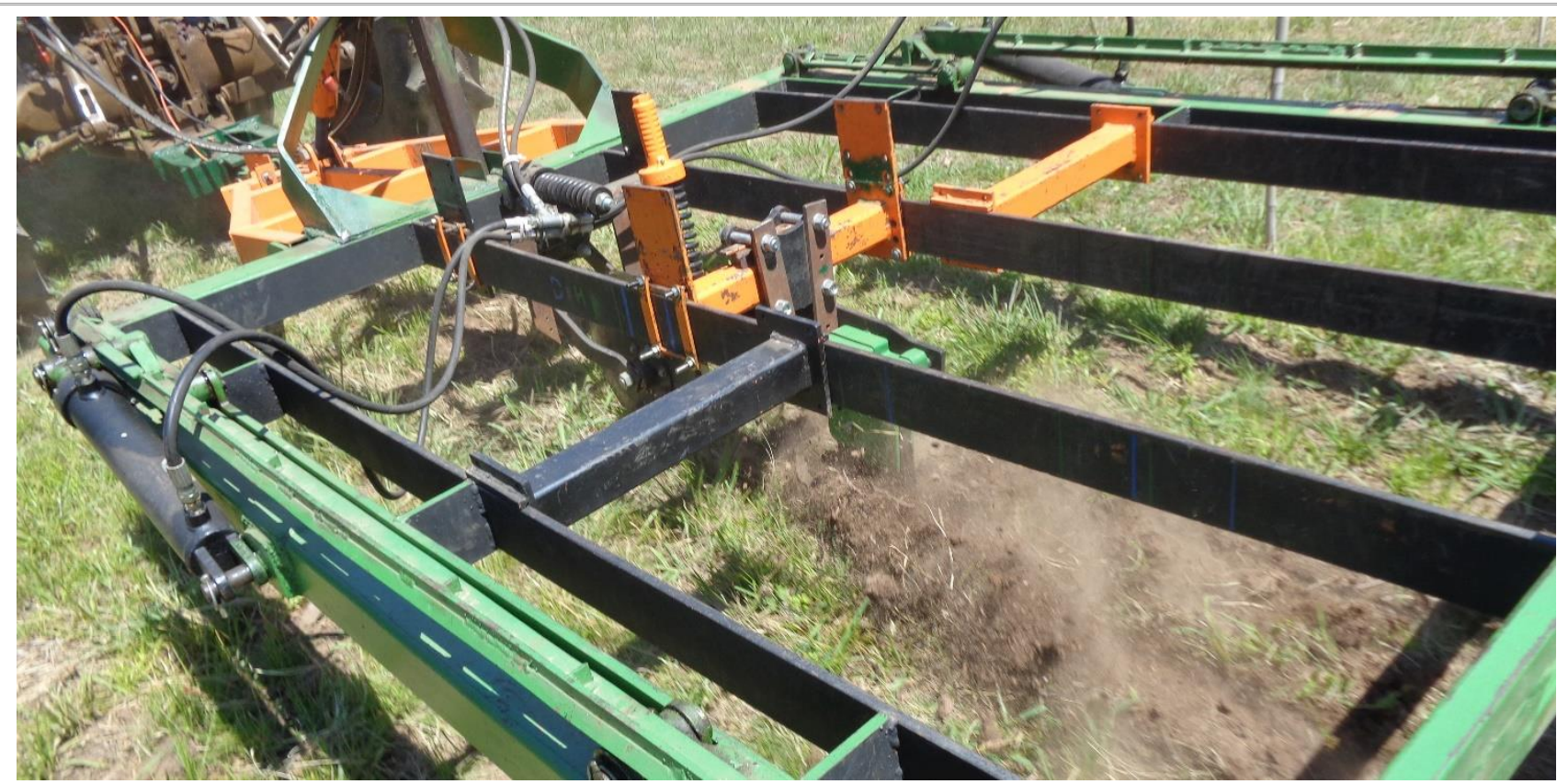

FIGURE 8. Reduction of the elevated area value by soil projection.

\section{Maximum furrow depth}

Figure 9 illustrates the variation in the maximum furrow depth for the different configurations, in addition to presenting the results of the Tukey test.

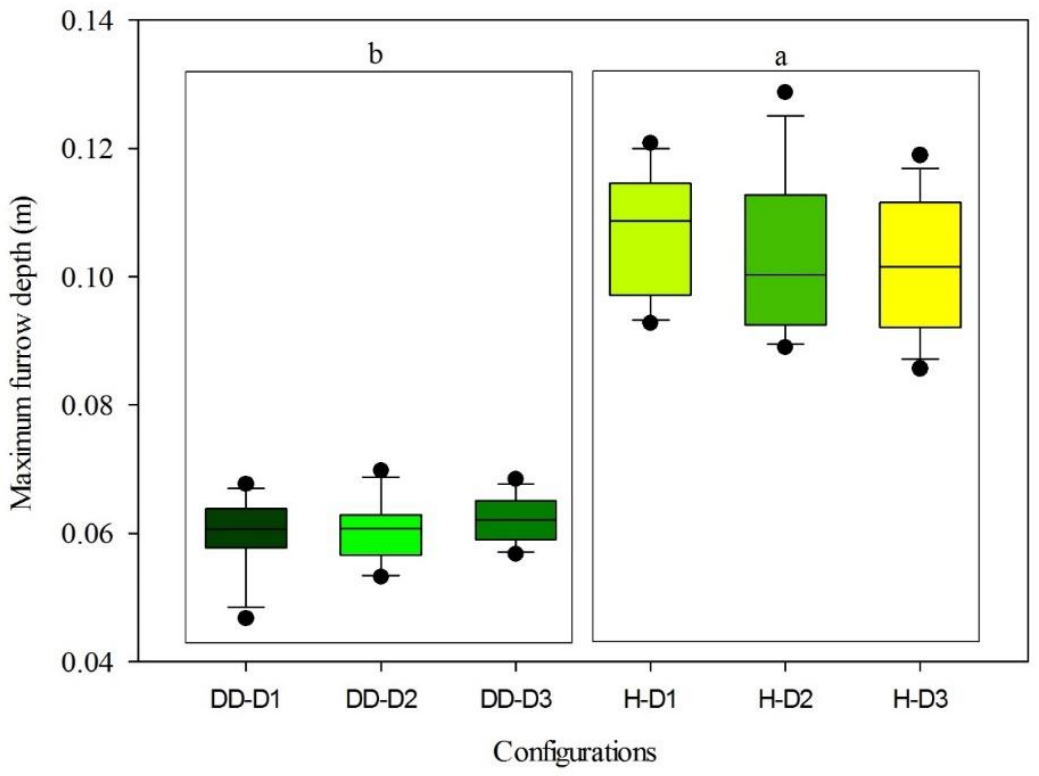

FIGURE 9. Maximum furrow depth for different furrow opener configurations

A group of configurations followed by different letters were significantly different according to the Tukey test $(\mathrm{p}<0.05)$.

The maximum depth responded to the type of hoe furrow opener. We obtained a mean of $0.1038 \mathrm{~m}$ for the hoe and $0.0610 \mathrm{~m}$ for the double disc, obtaining the regulated values for both. The latter presented a smaller depth of action as stated by Palma et al. (2010). In addition to its dimensional characteristics, it experiences more difficulty in penetrating the soil, as pointed out by Seidi (2012). Similar experimental results were obtained by Koakoski et al. (2007) and Mion et al. (2009). They attribute the hoe furrow opener reaching a greater depth to the action of the tip, which provokes a descending vector that allows suctioning of the hoe. However, the furrow opener presented the most significant instability in maintaining the set depth, with values that varied from 0.0857 to $0.1287 \mathrm{~m}$, corroborating the results of Karayel \& Özmerzi (2007).

Modifying the distance did not significantly alter the maximum depth of the furrow irrespective of the type of furrow opener employed. Hence, distance is a factor with no effect on selecting the kind of furrow opener and, consequently, on the work depth.

Figure 10 illustrates the unfolding of the interaction between the furrow opener and the forward speed on the maximum furrow depth. 


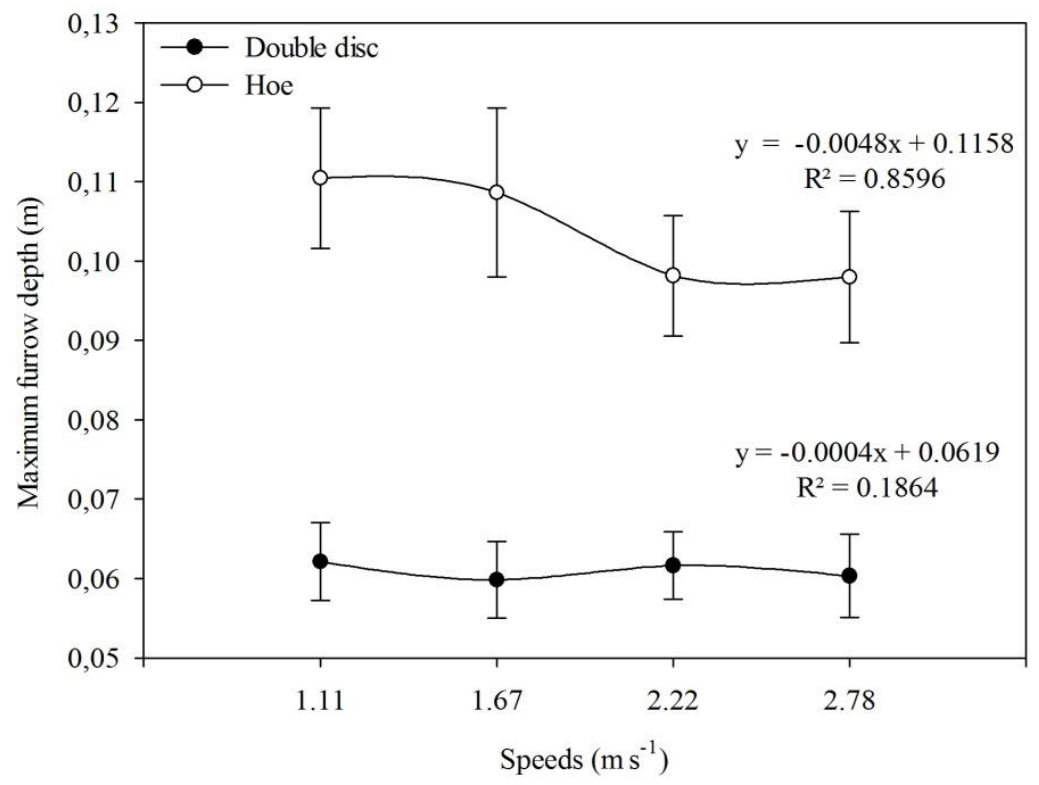

FIGURE 10. Interaction between furrow openers and speed on furrow depth.

The average maximum depth achieved by both furrow openers decreased with the increase in speed, reaching an average depth of $0.0863 \mathrm{~m}$ at $1.11 \mathrm{~m} \mathrm{~s}^{-1}$ and $0.0792 \mathrm{~m}$ at $2.78 \mathrm{~m} \mathrm{~s}^{-1}$, when analyzed jointly. Silveira et al. (2011), when assessing the furrow depth of a hoe in a maize seeding operation, also identified a reduction in this variable with an increase in forward speed. The authors pointed out that this behavior occurs because the fixed furrow opener tends to move closer to the surface at higher speeds, with resistance to penetration, soil moisture, and roughness being possible causes of variation.

The most significant impact on the change in depth as a function of elevating the work speed was observed for the fixed furrow opener, whereas the double disc opener always remained close to the adjusted value $(0.0610 \mathrm{~m})$.
Likewise, the coefficients of determination of the regression equations and the coefficients of the variable corroborate this statement, demonstrating that the hoe $\left(\mathrm{R}^{2}\right.$ : $0.8596 /-0.0048 \mathrm{x})$ is more susceptible to the alteration of the work depth with the increase in speed than the double disc $\left(\mathrm{R}^{2}\right.$ : $\left.0.1864 /-0.0004 \mathrm{x}\right)$, although both present a negative correlation (the factors and variables are inversely proportional). As a result, the selection of the work speed depends on the choice of the furrow opener, especially if it is not of the rotating type. Hence, to avoid this problem, the employment of speeds over $1.67 \mathrm{~m} \mathrm{~s}^{-1}$ must be avoided.

\section{Maximum furrow width}

Figure 11 illustrates the effect of the furrow opener type on the maximum width of the furrow.

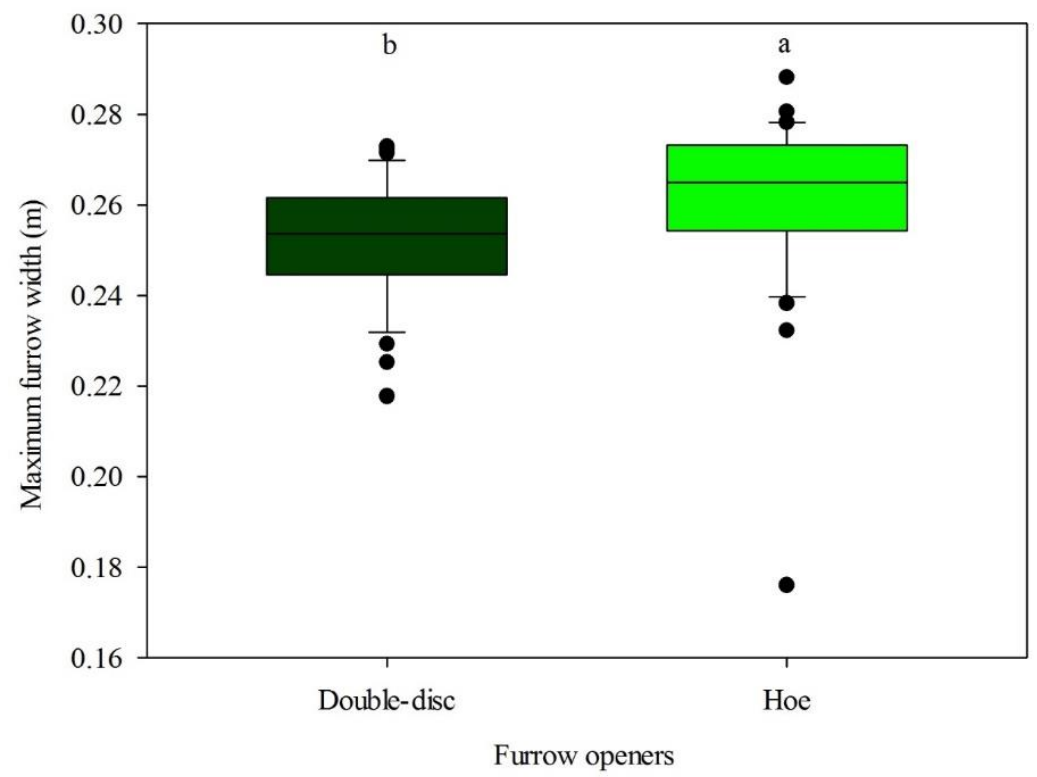

FIGURE 11. Maximum furrow width for the different furrow openers.

Furrow openers followed by different letters are significantly different according to the Tukey test $(\mathrm{p}<0.05)$. 
As expected, the furrow opener that worked at a greater depth created wider furrows, corroborating the results of Sánchez-Girón et al. (2005) and Hasimu \& Chen (2014). The hoe furrow opener presented the largest maximum furrow width $(0.2616 \mathrm{~m})$, whereas the double disc provided a narrower furrow $(0.2518 \mathrm{~m})$. The distance and speed factors did not significantly impact this variable, given that it remained at an average value of $0.2566 \mathrm{~m}$.

However, for both furrow openers, the setting that employed the smallest distance to the cutting mechanism presented the smallest maximum furrow width $(0.2512 \mathrm{~m})$, followed by the intermediary distance $(0.2566 \mathrm{~m})$, and the largest $(0.2621 \mathrm{~m})$, irrespective of the speed employed. This effect may be caused by the fact that, at closer distances, the cutting disc starts the formation of the furrow along with the furrow openers; when distancing such mechanisms, the soil mobilized by the cutting mechanism returns to the furrow and, because it is turned over, is launched further away from the furrow center upon the passing of the furrow openers through this site.

\section{Soil swelling}

Figure 12 illustrates the soil swelling for the double-disc and hoe furrow openers in different settings.

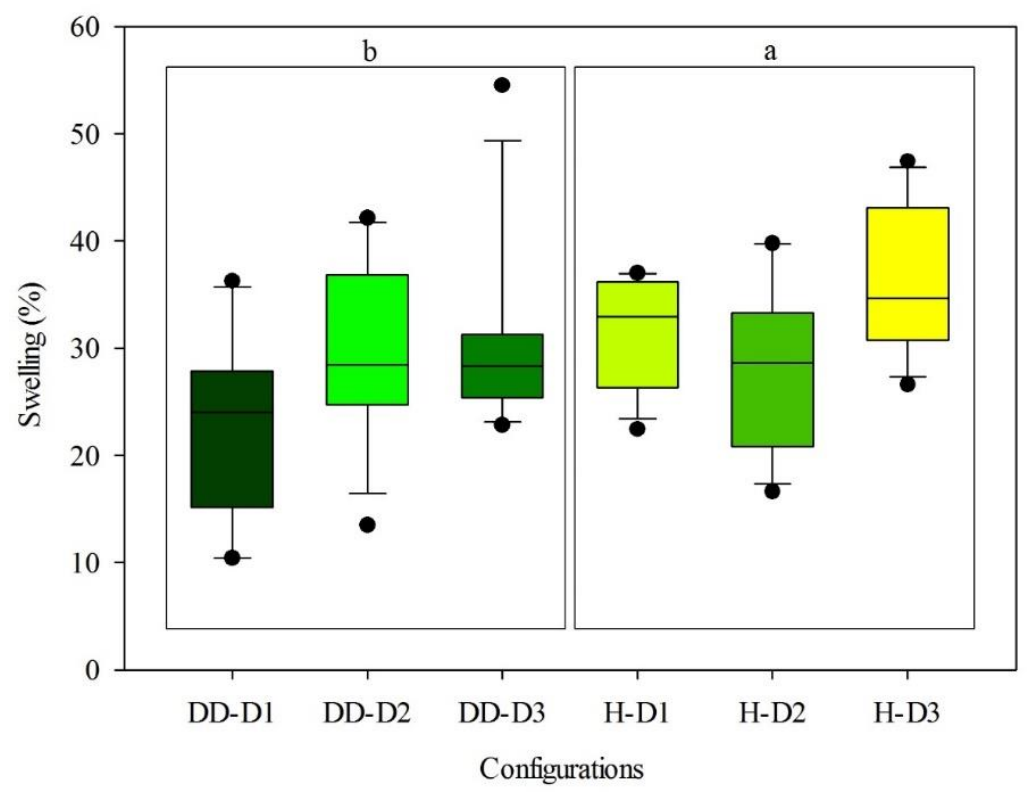

FIGURE 12. Soil swelling as a function of the mechanism configuration.

A group of configurations followed by different letters were significantly different according to the Tukey test $(\mathrm{p}<0.05)$.

The hoe furrow opener, compared to the double disc, presented the most significant swelling, with an average of $31.82 \%$ for the former and $27.65 \%$ for the latter. This difference represented an increase of $13.10 \%$ in the soil volume of the fixed as compared to the rotating furrow opener. This is because the hoe furrow opener provides a higher index of spaces among soil particles than the double discs, a result of the shearing action performed instead of soil cutting (Francetto et al., 2016).

The distance factor significantly altered the soil swelling. We obtained a mean value of approximately $30 \%$ for the different furrow openers in the increase of the soil volume. However, the closest condition to the cutting disc yielded a mean value of $27.09 \%$, compared to $33.18 \%$ at the most distant. The regression that expresses the behavior of the variable as a function of the modification of the distance factor is $y=0.0119 x^{2}-0.0173 x+0.2762$ $\left(\mathrm{R}^{2}=1\right)$. For the double-disc furrow opener, there was a reduction of this variable with the decrease in the distance between the tools; however, for the hoe opener, this trend was only found when comparing distance $3(1.5 \mathrm{~m})$ with distance $1(0.50 \mathrm{~m})$. For the respective furrow opener at the intermediary distance $(1.0 \mathrm{~m})$, we verified an experimental error, given the reduced mobilized soil area found, which was associated with the variability in the local physical characteristics of the soil.
Because the swelling stems from the ratio between the elevated and the mobilized soil area and because none suffered changes due to the increase in speed, the swelling also did not present statistical differences when the speed factor was assessed.

\section{CONCLUSIONS}

1- The modifications pertaining to the fertilizer furrow opening mechanism, distance between the cutting disc and fertilizer furrow opener, and work speed caused changes in the soil movement. The following conclusions were drawn from the tests performed to measure these changes in soil movement under the conditions of this study.

2- The mobilized soil area suffered alteration only with the furrow opening factor, which was more significant for the hoe furrow opener, and the change in distance and speed was shown to be extrinsic to this.

3 - The reduction in the distance between the cutting mechanism and furrow openers decreased the soil elevation and swelling, with these variables being higher for the configurations employing the hoe furrow opener.

4- The maximum width and depth of the furrow were affected only by the furrow opener factor.

5 - We recommend the installation of the fertilizer furrow openers close to the cutting mechanisms for culture residues when they are employed in seeder-fertilizer spreaders used in direct planting systems. 


\section{ACKNOWLEDGMENTS}

This research was supported financially by the Coordination for the Improvement of Higher Education Personnel (CAPES).

\section{REFERENCES}

Aguilera E, Guzmán GL, Molina MG, Soto D, InfanteAmate J (2019) From animals to machines. The impact of mechanization on the carbon footprint of traction in Spanish agriculture: 1900-2014. Journal of Cleaner Production 221: 295-305. DOI:

http://dx.doi.org/10.1016/j.jclepro.2019.02.247

Amoozad-Khalili M, Rostamian R, Esmaeilpour-Troujeni M, Kosari-Moghaddam A (2020) Economic modeling of mechanized and semi-mechanized rainfed wheat production systems using multiple linear regression model. Information Processing in Agriculture 7: 30-40. DOI: http://dx.doi.org/10.1016/j.inpa.2019.06.002

Bellé MP, Alonço AS, Francetto TR, Rossato FP, Franck CJ, Carpes DP (2014) Demanda energética e mobilização do solo com o uso de escarificadores em sistemas de semeadura direta. Revista Brasileira de Engenharia Agrícola e Ambiental 18: 551-558. DOI: http://dx.doi.org/10.1590/S1415-43662014000500013

Blanco-Canqui H, Ruis SJ (2018) No-tillage and soil physical environment. Geoderma 326: 164-200. DOI: http://dx.doi.org/10.1016/j.geoderma.2018.03.011

Büchi L, Georges F, Walder F, Banerjee S, Keller T, Six J, Heijden MVD, Charles R (2019) Potential of indicators to unveil the hidden side of cropping system classification: Differences and similarities in cropping practices between conventional, no-till and organic systems. European Journal of Agronomy 109: 125920. DOI: http://dx.doi.org/10.1016/j.eja.2019.125920

Carpes DP, Alonço AS, Veit AA, Souza LB, Francetto TR (2017) Effect of different conductor tubes on the longitudinal distribution of corn seeds. Revista Brasileira de Engenharia Agrícola e Ambiental 21: 657-662. DOI: http://dx.doi.org/10.1590/1807-1929/agriambi.v21n9p657-662

Casão Junior R, Araújo AG, Ralisch R (2000)

Desempenho da semeadora-adubadora magnum $2850 \mathrm{em}$ plantio direto no basalto paranaense. Pesquisa Agropecuária Brasileira 35: 523-532. DOI: http://dx.doi.org/10.1590/S0100-204X2000000300007

Dang YP, Moody PW, Bell MJ, Seymour NP, Dalal RC, Feebairn DM, Walker SR (2015) Strategic tillage in no-till farming systems in Australia's northern grains-growing regions: II. Implications for agronomy, soil and environment 152: 115-123. DOI:

http://dx.doi.org/10.1016/j.still.2014.12.013

Daum T, Birner R (2020) Agricultural mechanization in Africa: Myths, realities and an emerging research agenda. Global food security 26: 100393. DOI: http://dx.doi.org/10.1016/j.gfs.2020.100393
EMBRAPA - Empresa Brasileira de Pesquisa

Agropecuária (1997) Manual de métodos de análise de solo. Embrapa Solos, 212p. Available:

http://www.agencia.cnptia.embrapa.br/Repositorio/Manual +de+Metodos_000fzvhotqk02wx5ok0q43a0ram31wtr.pdf. Accessed Mar 23, 2020

EMBRAPA - Empresa Brasileira de Pesquisa Agropecuária (2013) Sistema brasileiro de classificação de solos. Embrapa Solos, 353p.

Francetto TR, Alonço AS, Brandelero C, Machado ODC, Veit AA, Carpes DO (2016) Disturbance of ultisol soil based on interactions between furrow openers and coulters for the no-tillage system. Spanish Journal of Agricultural Research 14: e0208. DOI: http://dx.doi.org/10.5424/sjar/2016143-9148

Gassen JRF, Alonço AS, Baumhardt UB, Bellé MP, Bonotto GJ (2014) Resistência específica à tração na operação de escarificação do solo em camadas de forma simultânea. Revista Brasileira de Engenharia Agrícola e Ambiental 18: 116-124. DOI:

http://dx.doi.org/10.1590/S1415-43662014000100015

Gassen JRF (2011) Avaliação de ferramenta para escarificação do solo em camadas de forma simultânea. PhD Thesis, Universidade Federal de Santa Maria, Programa de Pós-Graduação em Engenharia Agrícola.

Hasimu A, Chen Y (2014) Soil disturbance and draft force of selected seed openers. Soil \& Tillage Research 140: 4854. DOI: http://dx.doi.org/10.1016/j.still.2014.02.011

Jabro JD, Stevens WB, Iversen WM, Sainju UM, Allen BL (2021) Soil cone index and bulk density of a sandy loam under no-till and conventional tillage in a corn-soybean rotation. Soil and Tillage Research 206: 104842. DOI: http://dx.doi.org/10.1016/j.still.2020.104842

Karayel D, Özmerzi A (2007) Comparison of vertical and lateral seed distribution of furrow openers using a new criterion. Soil and Tillage Research 95: 69-75. DOI: http://dx.doi.org/10.1016/j.still.2006.11.001

Koakoski A, Souza CMA, Rafull LZL, Souza LCF, Reis EF (2007) Desempenho de semeadora-adubadora utilizando-se dois mecanismos rompedores e três pressões da roda compactadora. Pesquisa Agropecuária Brasileira 42: 725-731. DOI: http://dx.doi.org/10.1590/S0100204X2007000500016

Liu H, Crawford M, Carvalhais LC, Dang YP, Dennis PG, Schenk PM (2016) Strategic tillage on a grey vertosol after fifteen years of no-till management had no short-term impact on soil properties and agronomic productivity. Geoderma 267: 146-155. DOI: http://dx.doi.org/10.1016/j.geoderma.2016.01.002

Loon JV, Woltering L, Krupnik TJ, Baudron F, Boa M, Govaerts B (2020) Scaling agricultural mechanization services in smallholder farming systems: Case studies from sub-Saharan Africa, South Asia, and Latin America. Agricultural Systems 180: 102792. DOI: http://dx.doi.org/10.1016/j.agsy.2020.102792 
Mion RL, Benez SH, Viliotti CA, Moreira JB, Salvador N (2009) Análise tridimensional de esforços em elementos rompedores de semeadoras de plantio direto. Ciência Rural 39: 1414-1419. DOI: http://dx.doi.org/10.1590/S010384782009005000067

Nawaz A, Farroq M, Ahmad R, Basra SMA, Lal R (2016) Seed priming improves stand establishment and productivity of no till wheat grown after direct seeded aerobic and transplanted flooded rice. European Journal of Agronomy 76: 130-137. DOI:

http://dx.doi.org/10.1016/j.eja.2016.02.012

Nunes MR, Es HMV, Schindelbeck R, Ristow AJ, Ryan M (2018) No-till and cropping system diversification improve soil health and crop yield. Geoderma 328: 30-43. DOI: http://dx.doi.org/10.1016/j.geoderma.2018.04.031

Palma MAS, Volpato CES, Barbosa JA, Spagnolo RT, Barros MM, Boas LAV (2010) Efeito da profundidade de trabalho das hastes sulcadoras de uma semeadoraadubadora na patinagem, na força de tração e no consumo de combustível de um trator agrícola. Ciência e Agrotecnologia 34:1320-1326. DOI: http://dx.doi.org/10.1590/S1413-70542010000500034

Paudel GP, KC DB, Rahut DB, Justice SE, McDonald AJ (2019) Scale-appropriate mechanization impacts on productivity among smallholders: Evidence from rice system in the mid-hills of Nepal. Land use policy 85: 104113. DOI: http://dx.doi.org/10.1016/j.landusepol.2019.03.030

Sánchez-Girón V, Ramírez JJ, Litago JJ, Hernanz JL (2005) Effect of soil compaction and water content on the resulting forces acting on three seed drill furrow openers. Soil and Tillage Research 81: 25-37. DOI: http://dx.doi.org/10.1016/j.still.2004.04.003
Seidi E (2012) Effects of geometry of disk openers on seed slot properties. World Academy of Science, Engineering and Technology 72:83-87.

Silva PRA, Benez SH, Jasper SP, Seki AS, Masiero FC, Riquetti NB (2012) Semeadora-adubadora: mecanismos de corte de palha e cargas verticais aplicadas. Revista Brasileira de Engenharia Agrícola e Ambiental 16: 13671373. DOI: http://dx.doi.org/10.1590/S141543662012001200015

Silveira JCM, Fernandes HC, Modolo AJ, Silva SL, Trogello E (2011) Furrow depth, soil disturbance area and draft force of a seeder-fertilizer at different seeding speeds. Revista Ceres 293-298. DOI: http://dx.doi.org/10.1590/S0034-737X2011000300008

Skaalsveen K, Ingram J, Urquhart J (2020) The role of farmers' social networks in the implementation of no-till farming practices. Agricultural Systems 181: 102824. DOI: http://dx.doi.org/10.1016/j.agsy.2020.102824

Solhjou A, Fielke JM, Desbiolles JMA, Saunders C (2014) Soil translocation by narrow openers with various bent leg geometries. Biosystems Engineering 127: 41-49. DOI: http://dx.doi.org/10.1016/j.biosystemseng.2014.08.008

Sun J, Wang Y, Ma Y, Tong J, Zhang Z (2018) DEM simulation of bionic subsoilers (tillage depth $>40 \mathrm{~cm}$ ) with drag reduction and lower soil disturbance characteristics. Advances in Engineering Software 119: 30-37. DOI: http://dx.doi.org/10.1016/j.advengsoft.2018.02.001

Zeng Z, Chen Y, Zhang X (2017) Modelling the interaction of a deep tillage tool with heterogeneous soil. Computers and Eletronics in Agriculture 143: 130-138. DOI: http://dx.doi.org/10.1016/j.compag.2017.10.005 